\title{
Izglītības jomā strādājošo supervizoru profesionālā kompetence
}

\section{Inga Remerte, Baiba Pumpinga}

Iesākumā ir būtiski apskatīt jēdziena "profesionālā kompetence" definīciju, lai veidotos vienota izpratne, jo šis jēdziens dažādās zinātnes disciplīnās ir zināms jau ilgstoši un tiek skaidrots dažādi. Turklāt laika gaitā izkristalizējušās un mainījušās defin̄icijas, skaidrojumi un komentāri, un tas viennozīmīgi liecina, ka šis jēdziens nav statisks. 2009. gada 29. septembrī par termina "kompetence" izpratni un lietošanu latviešu valodā ir pieņemts Latvijas Zinātņu akadēmijas Terminoloǵijas komisijas lēmums Nr. 84, atzīstot tā divas nozīmes:

1) nepieciešamās zināšanas, profesionālā pieredze, izpratne kādā noteiktā jomā, jautājumā un prasme zināšanas un pieredzi izmantot konkrētā darbībā. Personas (darbinieka) kompetenci vērtē apkārtējie cilvēki, sadarbības partneri, sabiedrība;

2) piekritība, tiesīgums (kādā jautājumā), pilnvaru kopums; sfēra, par ko ir uzdota atbildība, n,emot vērā personas izglītību, spējas, zināšanas un pieredzi attiecīgajā jomā.

Kompetence tiek skaidrota arī kā plašas zināšanas kādā jomā, jautājumā un darba sfērā. Tā ir gatavība darbībai, subjekta izziņas vajadzība, personības attīstības veseluma procesuāls un integrējošs rādītājs, individuāli psiholoǵiska, sociāla kvalitāte, spējas, kas nodrošina sekmīgu darbības veikšanu, kā arī amatpersonu pilnvaru apjoms, to īstenošanas pārzināšana, liecinot par profesionālo kompetenci, sociālo kompetenci un individuālās attīstības jeb sociālās kultūras kompetenci. Š̄is kompetences ir savstarpēji saistītas un nav nodalāmas, taču akcentē konkrētas jomas darbības virzienu (Garleja, 2006). Kompetence tiek definēta kā efektīvas darbības demonstrēšana, spēja veikt uzdevumus reālā vai imitētā darba situācijā. Kompetences pamats ir kvalifikācija. Savukārt kvalifikācija tiek definēta kā attiecīgu zināšanu, spēju, iemaņu un pieredzes kopums, kuras apgūstot cilvēks var kvalitatīvi (kompetenti) strādāt atbilstoša veida un sarežǵītības darbu. 
Kompetence ir saistīta ar cilvēka darbību, un tās saturisko struktūru veido divu komponentu mijiedarbība:

1) individuālajā pieredzē balstītas kognitīiās, emocionālās, voluntārās, fiziskās, sociālās un metakognitīvās spējas, kas ir cilvēka individuālais potenciāls;

2) pašpieredze, citu un pasaules pieredzes gūšanas iespējas (Laužackas, 1999).

Analizējot zinātnieku pieejas kompetences jēdziena izpratnē, atklājās tās saistība ar tādiem jēdzieniem kā "lietpratība" (to varētu uzskatî̀ arī par vārda "kompetence" sinonīmu), "kvalifikācija" un "meistarība". Kompetences skaidrojumā (atškiirībā no kvalifikācijas) ir īpaši uzsvērta darbība, skaidrojot to kā gatavību profesionālai darbībai. Kompetence ir izglîtības procesā gūtās zināšanas, prasmes, spējas, attieksme, vērtības un pieredze, kas noteiktā dzīves posmā tiek iegūta, attīstīta un pilnveidota visā profesionālās darbības laikā. Kompetence ir spēja parādīt vispusīgas un specializētas attiecīgajai profesionālajai jomai atbilstošas faktu, teoriju, likumsakarību un tehnoloǵiju zināšanas un izpratni. Tā ir saistìta ar subjekta spēju sekmīgi rīkoties jaunās sarežg̣îtās situācijās (Puḳîte, 2012). Analizējot definīcijas, kurās raksturota kompetence, var konstatēt, ka to autori lielākoties identificē un apskata virkni faktoru - pazīmes vai raksturojumus, elementus, kas ir būtiski, lai profesionāḷi darbotos sekmīgi un efektīivi. Definīcijās uzmanība tiek pievērsta tam, kādas ir nozīmīgākās spējas, kas ir nepieciešamas profesionālim, lai viņš spētu sekmīgi veikt konkrētu darbu.

Var izdalīt vairākus definīciju struktūras komponentus:

1) personības īpašības, kas nodrošina noteiktas rīcības izpausmes noteiktās situācijās;

2) emocionālo noturību un spēju mainīties, pielāgoties;

3) prasmes, kas nepieciešamas konkrētu uzdevumu veikšanai un ko pārsvarā apgūst, mācoties un/vai gūstot pieredzi;

4) attieksmes, vērtības, motīvi, kas rosina un vada uz noteiktām darbībām un ir individuālie pien̄ēmumi par to, kas ir pareizi un kas - nepareizi;

5) vispārējas un specifiskas zināšanas (arī papildinformācija) noteiktās jomās;

6) pieredzi, kas pārsvarā tiek gūta, mācoties no savas un citu pieredzes;

7) sociālās saites - attiecības ar citiem cilvēkiem (Golubeva, 2010).

Līdz ar visu iepriekš minēto iezīmējas profesionālās kompetences skaidrojums tās ir zināšanas, prasmes, spējas, attieksme, vērtības un pieredze, kas noteiktā dzīves posmā tiek iegūta, attīstīta un pilnveidota visā profesionālās darbības laikā. Taču ir svarīgi uzsvērt, ka profesionālā kompetence nav tikai šo iepriekšminēto vienību atsevišķa esība profesionālim, bet arī to organiska apvienošana un izmantošana profesijā. Tas ir vienots, nedalāms komplekss, ko profesionālis izmanto, lai darbotos profesijai noteikto funkciju izpildē.

Supervizora profesionālās darbības veikšanai nepieciešamās prasmes un attieksmes, vispārējās un profesionālās zināšanas un kompetences ir noteiktas 
I. Remerte, B. Pumpina. Izglīīibas jomā strādājošo supervizoru profesionālā kompetence

Supervizora profesijas standartā, kur ir norādīti 25 uzdevumi, kā arī katra uzdevuma izpildei nepieciešamās prasmes un attieksmes, profesionālās zināšanas un kompetences. Supervizora profesijas standarts ir veidots saskaņā ar Eiropas Nacionālo supervīzijas organizāciju apvienības (Association of National Organisation for Supervision in Europe, ANSE) izstrādāto kompetenču modeli. Profesijas standarts var tikt izmantots gan pašnovērtējuma, gan arī kontroles vajadzībām, izvērtējot savas prasmes un attieksmes, profesionālās zināšanas un kompetences. Supervizoram ir būtiski uzdot sev šādus jautājumus: "Kādas ir manas stiprās puses, un kas ir jāpilnveido? Kādas darbības ir nepieciešamas, lai es varētu uzlabot savas prasmes, attieksmi, zināšanas un kompetenci?"

Supervizora darbā nepieciešamās kompetences var aplūkot arī saistībā ar supervīzijas funkcijām, un tās ir: 1) izglītojošā; 2) atbalstošā; 3) administrējošā (pārraudzības, vadības) funkcija. Izglītojošā funkcija papildina supervīzijas dalībnieka zināšanas, attīsta viņa prasmes un izpratni, veicina viņa mācī̌sanos, dodot iespēju reflektēt par praksi, tā nodrošina speciālista personīgo un profesionālo izaugsmi.

Izglītojošā supervīzija dod ieguldījumu, lai personisku patību pārveidotu profesionālajā patībā, un tā ir viena no metodēm, kas nodod tālāk profesionālās zināšanas, prasmes, iemaņas un vērtības (Driscoll, 2004; Carroll, 1999; Zonga, 1997, citēts no Truskovska, 2013). Atbalstošā funkcija ir jāsaprot kā profesionāli atbalstoša darbība supervīzijā. Tā lauj atgūties no negatīvām emocijām, attīsta speciālistu spēju darboties paaugstināta stresa apstākḷos un laikus pamanīt profesionālās izdegšanas potenciālos riska faktorus (Āboltiņa, 2012). Savukārt administrējošā funkcija palīdz veikt darbu, saglabājot kontroli un atbildību par paveikto. Katra no trīs supervīzijas funkcijām tikai daḷēji sniedz priekšstatu par supervīzijas saturu - funkcijas un to uzdevumi papildina cits citu, jo ir savstarpēji saistīti un nereti arī pārklājas (Āboltiņa, 2012). Katra no tām ir specifiska un būtiska, tās nav strikti nodalāmas un realizējamas atsevišķi. To, kura funkcija supervīzijā dominēs, nosaka supervizējamo profesionālās vajadzības, supervizora teorētiskā pieeja, kā arī supervīzijas mērḳis un uzdevumi. Tas ir būtiski, jo supervīzijas funkcijas iezīmē arī dažādas supervizora lomas - ar noteiktu attieksmi pret klientu, noteiktām attiecībām un sadarbības stilu.

Supervizoram, strādājot izglītības vidē, noteikti jāṇem vērā atškirības dažādās pedagogu mērkgrupās - ir pirmsskolas, sākumskolas, pamatskolas, vidusskolas pedagogu un izglīīības iestāžu vadītāju grupas. Starp tām noteikti nav liekama vienādības zīme, jo katrai no tām būs raksturīgas atškirīgas supervīzijas vajadzības. Ne mazāk svarīgi ir arī citi faktori: skolas atrašanās vieta (pilsētā vai ārpus pilsētas), skolēnu skaits skolā u. c. raksturlielumi - tie ietekmē gan savstarpējās attiecības (pedagogs-skolēns, pedagogs-vecāks, pedagogs-pedagogs, skolēns-skolēns), gan resursu pieejamību. 
Iepriekš minētie faktori ir nozīmīgi profesionālās kompetences specifikas noskaidrošanai, galvenokārt kontekstā ar supervīzijas pasūtītāja un/vai supervizējamā vajadzību, profesionālo grūtību un gaidu noskaidrošanu. N̦emot vērā supervīzijas funkciju un veidu (individuālā, grupas vai komandas), var tikt apskatītas supervizoram nepieciešamās specifiskās zināšanas.

Šì raksta autore no 2020. gada 15. janvāra līdz 2020. gada 15. martam veica pilotaptauju, kurā piedalījās 60 pedagogi no dažādām Latvijas skolām. Analizējot rezultātus, tika secināts, ka 38\% respondentu kā savu primāro vajadzību supervīzijai izvirza zināšanu pilnveidošanu par darba metodēm skolēnu motivēšanai, 20\% metodes pārslodzes un izdegšanas mazināšanai, 11\% - mācību metožu dažādošanas iespējas, dalīšanos ar labās prakses piemēriem, 7\% aptaujāto supervīzijā vēlējās strādāt ar jautājumiem par darbu ar skolēniem, kuriem ir mācīšanās grūtības, 5\% norādīja, ka viņus interesējošie jautājumi ir darbs un komunikācija ar vecākiem un sadarbība ar kolēgiem, 3\% ir aktuāla iespēja gūt gandarījumu par darbu.

N̦emot vērā aptaujas rezultātus, var secināt, ka supervizora darbā izglītības vidē īpaši nozīmīga ir izglītojošā funkcija. Zināšanas par mācību metožu, darba organizācijas formu un līdzekḷu izvēli ḷauj bagātināt skolotāju kompetenci. Supervizoram jāpārzina un jāizprot arī tādi jautājumi kā pedagoga loma motivācijas veidošanā (motivācijas teorijas, motivācijas rīki), skolēnu vecumposmu un dzimuma īpatnības, psihoemocionālā riska faktori un pasākumi to mazināšanai. Nozīmīga ir supervizora spēja pamanīt izdegšanas riskus, vienlaikus būt atbalstošam, palīdzēt atrast efektīvākos rīkus pašregulācijai un resursu papildināšanai, informēt par preventīviem pasākumiem psihoemocionālo risku mazināšanai skolotāja darbā. Izglîtības vides specifikas dēḷ (piemēram, skolotājs nevar paņemt pauzi stresa brīdī, jo viņam jāatrodas klasē un jāvada stunda) nozīmīga ir supervizora spēja radīt drošu vidi, kur uzkrātās emocijas reflektēt, tā mazinot spriedzi un profesionālās šaubas. Svarīgas ir zināšanas psihologijāā, izpratne par pieaugušo mācīšanās un vecumposmu īpatnībām.

Izglîtības vidē līdz šim supervīzija vairāk realizēta darbā ar grupām un komandām. Tam nepieciešamas zināšanas par organizācijas funkcionēšanas un vadības principiem, grupas un komandas veidošanās, attīstības un dinamikas procesiem, ir jāorientējas lēmumu pieņemšanas stratēgijās un konfliktu risināšanas metodēs, jāprot vadīt varas aspektus. Vienojoties par supervīzijas gaitu, mērkiem un uzdevumiem, supervizoram jāprot izvērtēt, kāds ir lietderīgums vadītāja (mācību iestādes direktora) dalībai grupā, kā arī jāspēj to pamatot. Darbā ar komandu supervizora loma ir palīdzēt tai apzināties esošos procesus, stimulēt risinājumu meklējumus, sniegt atgriezenisko saiti par savu redzējumu, rekomendēt nepieciešamās darbības vai aktivitātes pārmaiņu veicināšanai. Supervizoram jāspēj saskatīt sakarības starp supervizējamo rīcību un uzvedību, kā arī organizācijas kontekstu un kultūru, vienlaikus radot apstākḷus, kur supervīzijas dalībnieki var paši apzināties notiekošo. 
I. Remerte, B. Pumpiṇa. Izglītības jomā strādājošo supervizoru profesionālā kompetence

Līdztekus visam iepriekšminētajam supervizoram, strādājot izglītības vidē, savā darbā ir svarīgi ievērot augstus ètikas standartus. Īpaši jāmin spēja saglabāt konfidencialitāti, jo nereti supervīzijās tiek izgaismota sensitīva informācija, kas skar bērnu tiesības. Svarīgi ir pievērst uzmanību notiekošajam sociumā, īpaši izglītības jomā - pārzināt un izprast procesus, pārzināt likumdošanu, būt informētam par jaunākajiem zinātniskajiem pētījumiem, veidojot un uzturot atbildīgu supervīzijas praksi.

L. Turuševa savā promocijas darbā definē, kas nepieciešams, lai uzturētu profesionālo kompetenci vajadzīgajā līmen̄̄ (Turuševa, 2010):

1) nepārtraukti jāinteresējas par jaunumiem savā profesijā un mērķklientu profesionālajā vidē;

2) jānovēro un jāpapildina sava kompetence caur pašnovērtēšanu, kontroli un konsultāciju;

3) jābūt informētam par nacionāliem un starptautiskiem lēmumiem, noteikumiem un prasībām.

Profesionālā kompetence veidojas, attīstās un pilnveidojas visas dzīves garumā, un to ietekmē dažādi faktori. Tādēḷ ir nepieciešama nepārtraukta zināšanu un iemaņu paplašināšana - profesionālās literatūras las̄̄̌sana, mācību semināru un supervīzijas par supervīziju apmeklēšana. Prasmes, kas vajadzīgas konkrētu uzdevumu veikšanai, tiek apgūtas, mācoties un gūstot pieredzi. Attīstoties prasmēm un paplašinoties zināšanām, pilnveidojas spējas. Supervīzija ir process, kur norit cieša mijiedarbība starp tās dalībniekiem; šajā procesā mācās un iegūst visi tās dalībnieki, arī supervizors, kurš mācās no dz̄ivesgudriem skolotājiem.

\section{Avoti un literatūra}

Āboltiņa, L. (2012). Reflektīvā darbība sociālo darbinieku supervīzijāa. (Promocijas darbs). Iegūts no: https://dspace.lu.lv/dspace/bitstream/handle/7/4663/20124-Liga_ Aboltina_2012.pdf? sequence=1

Garleja, R. (2006). Cilvēkpotenciāls sociālajā vidē. Rīga: RaKa.

Golubeva, A. (2010). Studiju programmas direktora kā vadītāja darbības kompetence un profesionālā pilnveide. (Promocijas darbs). Iegūts no: https://dspace.lu.lv/dspace/ bitstream/handle/7/5058/16989Ausma_Golubeva_2010.pdf?sequence=1\&isAllowed=y

Laužackas, R. (1999). Profesionālās izglìtības satura reforma: didaktiskās iezīmes. Rīga: RaKa.

Latvijas Zinātṇu akadèmijas Terminologijas komisijas lēmums Nr. 84. Iegūts no: http:// termini.lza.lv/article.php?id=301

Puķīte, M. (2012). Medicīnas studentu pedagogiskās kompetences veidošanās studiju procesā. (Promocijas darbs). Iegūts no: https://dspace.lu.lv/dspace/bitstream/handle/7/4678/20716Margarita_Pukite_2012.pdf? sequence $=1 \&$ isAllowed $=y$ 
I. Remerte, B. Pumpinga. Izglìtības jomā strādājošo supervizoru profesionālā kompetence

Valsts izglìtības satura centrs. Supervizora profesijas standarts. Iegūts no: https://visc.gov. lv/profizglitiba/do.kumenti/standarti/2017/PS-109.pdf

Truskovska, Ž. (2013). Sociālā pedagoga profesionālās kompetences veidošanās supervīzijā. (Promocijas darbs). Iegūts no: https://dspace.lu.lv/dspace/bitstream/handle/7/4933/40481Zenija_Truskovska_2013.pdf?sequence $=1$

Turuševa, L. (2010). Ārējo sakaru struktūrvienības vadītāja profesionālā kompetence un tās veidošanās studiju procesā. (Promocijas darbs). Iegūts no: https:// dspace.lu.lv/dspace/bitstream/handle/7/4576/16686-Larisa_Turuseva_2010.pdf? sequence $=1 \&$ isAllowed $=\mathrm{y}$ 